\title{
Evaluation of the Bacterial Quality and Physicochemical Properties of Waterside River Ogbor-Hill Aba, Nigeria
}

\section{Samuel Ekene Odo ${ }^{1}$, Chibuzor Precious Emmanuel ${ }^{1,2}$, Nnenna Harriet Nwosu ${ }^{1}$, Felix Grace Chinomso ${ }^{1}$}

\author{
${ }^{1}$ Michael Okpara University of Agriculture, Umudike \\ PMB 7267, Umuahia Umudike, Abia State, Nigeria \\ 2 University of Chester \\ Parkgate Road, Chester, CH1 4BJ, United Kingdom
}

DOI: $10.22178 /$ pos.77-9

LCC Subject Category:

QH1-278.5

Received 21.11.2021

Accepted 25.12.2021

Published online 31.12.2021

Corresponding Author:

Odo Ekene Samuel

odo.samuel@mouau.edu.ng

(C) 2021 The Authors. This

article is licensed under a

Creative Commons Attribution

4.0 License @) (1)

\begin{abstract}
Safe water scarcity is one of Nigeria's critical challenges, and it is yet to receive adequate attention. Water-borne diseases and Water-related health problems are prevalent. This study evaluated the bacterial quality and physicochemical properties of Waterside River, Ogbor-Hill Aba, Nigeria. The pour plate technique was employed to analyse the 15 water samples obtained from Waterside River bacteriological analysis. The mean of Total Heterotrophic Bacteria

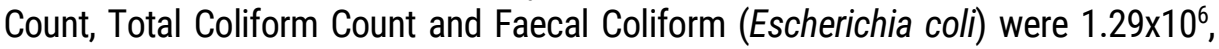
$7.4 \times 10^{5}$ and $3.2 \times 10^{5}$ colony forming units (CFU/ml), and the bacterial isolates were Citrobacter spp., Escherichia coli, Staphylococcus aureus, Salmonella spp., Pseudomonas aeruginosa and Shigella spp. The physicochemical parameters that were analysed by standard methods for the analysis of water and waste-water include Temperature, $\mathrm{pH}$, Lead $(\mathrm{Pb})$, Manganese $\left(\mathrm{Mn}^{+2}\right)$, Cadmium (Cd), Mercury $(\mathrm{Hg})$, Arsenic (As), Chromium $\left(\mathrm{Cr}^{6+}\right)$, Iron $\left(\mathrm{Fe}^{+2}\right)$, and Zinc $(\mathrm{Zn})$. All the physicochemical parameters determined were within the standards recommended by the Nigerian Industrial Standard and World Health Organization except $\mathrm{Pb}(0.21)$, $\mathrm{Mn}^{+2}(1.45), \mathrm{Hg}(0.002)$ and $\mathrm{Fe}^{+2}(1.03)$. The result shows that the Waterside River is unsafe for consumption and application in domestic activities except after proper treatment. The bacterial organisms Isolated have been found to cause diseases, and physicochemical parameters such as Lead $(\mathrm{Pb})$, Manganese $\left(\mathrm{Mn}^{+2}\right)$ and Mercury $(\mathrm{Hg})$ can lead to serious health challenges such as poisoning, neurological disorders and even death. Environmental laws that forbade the indiscriminate dumping of domestic and industrial wastes into the Waterside River should be enforced and defaulters sanctioned. Individuals, households and factories should stop transporting solid wastes and waste-water into the river and activities capable of causing pollution of the river should be discouraged.
\end{abstract}

Keywords: bacteriological analysis; chromium; faecal coliform; lead; physicochemical parameters; total coliform.

\section{INTRODUCTION}

One of the predominant and yet to be tackled problems facing sub-Saharan Africa, particularly Nigeria, is safe water scarcity. Environmental pollution is one of the major factors responsible for water contamination. Water-borne diseases and water-related infections are prevalent and increasingly threatening the capacity of Nigeria's health sector. The composition of water is dependent on its surrounding environment [6]. Water is one of the most important and precious natural resources required by living things and humans [33]. Access to safe drinking water is a fundamental human right and essential foundation of public health [24]. Surface water pollution and the consequent deterioration of aqueous systems are significant problems in developing and densely populated countries [10]. Increased urban, industrial and agricultural activities and failure to enforce environmental laws have resulted in the indiscriminate disposal of large volumes of untreated waste-water and solid wastes in rivers and streams [6]. These wastes contain harmful substances detrimental to human health, aquatic organisms and the ecosystem. 
Safe drinking water is crucial to human health and well-being [33]. Water used for domestic and industrial purposes should be safe and readily available. Unfortunately, an estimated 2 billion people drink faecally contaminated water, 4.5 billion people use a sanitation system that does not adequately protect their family or the downstream community from harm, and many vulnerable patients and students suffer from poor access to water sanitation and hygiene [13]. Unarguably, nations and individuals globally are confronted with water problems, predominant in developing countries such as Nigeria. Waterrelated diseases include diarrhoeal, intestinal helminths, schistosomiasis, trachoma, poliomyelitis, dracunculiasis, malaria, filariasis, and onchocerciasis are common health challenges linked to the consumption of contaminated water [22]. Other water-borne diseases such as cholera, campylobacteriosis, shigellosis, salmonellosis, typhoid and paratyphoid fever, and amoebic and bacillary dysentery are significant contributors to the dire state of health and high infant mortality rates, especially in developing countries of the world [26, 27, 4, 7, 29]. Diarrhoea is the second leading cause of death among children aged five years [31].

Clean and safe water is one of man's most important basic needs, daily used for domestic, industrial, and agricultural purposes. It is crucial to note that contaminated water is a significant and potential source of diseases, and water pollution has been linked to different human activities [28]. Poor hygiene and sanitation are the major causes of $88 \%$ of diarrhoea worldwide; it is disheartening that about 34-76 million people, primarily children, were estimated to die between 2000-2020 from preventable water-related diseases [26]. High mortality rate, infertility, low productivity, weak immune system and some damage to the organs of the body and body systems have been associated with consumption of polluted water $[27,4,32,29]$. Ecological degradation and the threat of climate change are contributing factors to safe drinking water scarcity and contamination. Other factors confronting the delivery of safe water to billions of people, especially in developing nations, include unchecked population growth and pollution of water sources with domestic wastes, industrial effluents, and chemicals such as pesticides, fertilisers, and insecticides used for agricultural purposes $[15,11,23]$. The consumption of contaminated water and its application in animal husbandry could be a key potential source of pathogenic organisms. It is essential to know that access to a safe and potable water supply is vital for good health $[10,21,20,14]$. Water composition is directly or indirectly dependent on the surrounding environment, and hence, environmental laws must be enforced and water bodies regularly monitored. Human activities around water sources contribute to the physicochemical and microbiological properties of the water $[17,8]$. However, improving drinking water supply and sanitation can reduce water-borne diseases [25, 31].

Waterside river is a deep freshwater river in Aba, Abia State, Nigeria, used for domestic, agricultural and industrial purposes [6]. However, there is the possibility that individuals may be depending on the Waterside River as their primary or alternative source of drinking water. Several industries, abbatoirs, laundry services units, and dumpsites are located near the river [3]. The Waterside area of Aba is densely populated, and the inhabitants depend on the Waterside River for most of their daily water needs; unfortunately, either bank of the waterside river, Ogbor-Hill Aba transverse the rear of many factories including breweries, soaps and detergent factories [12]. Some of these factories directly or indirectly channel waste-water into the river. Other prevailing activities capable of predisposing the river to contamination and pollution include that abattoir precisely hide and skin burning, auto mechanic workshops, and human wastes; faeces and urine. General refuse disposal by the teaming inhabitants can predispose the river to heavy pollution and contamination. These activities may compromise the river water quality, exposing users to substantial health risks. Hence, this current research focused on determining the river water's physicochemical properties and bacterial quality to determine if it is safe for consumption, including domestic use.

\section{MATERIALS AND METHODS}

Study Area. Waterside is a densely populated community in Aba, Abia State, and Southeast Nigeria. The Waterside River is the primary source of water used for daily activities by the inhabitants. Unfortunately, the river is exposed to anthropogenic activities capable of transferring contaminants into the river water. Effluents from factories near the river may directly or indirectly contaminate the river. Domestic refuse and 
waste water transported to the river bank and often directly into the river are potential contaminants.

Sample Collection. A total of fifteen water samples were collected from different locations from July to September 2021. Five samples were collected per month for three months. All the pieces were collected during the wet season. Each of the water samples was collected using a sterile $500 \mathrm{ml}$ container. The containers were washed thoroughly and sterilised using 70\% ethanol. The container's cap was unscrewed and held at its base. It was then plunged downwards below the surface directing its mouth towards the water current. Each container was carefully removed and corked after taking the required quantity of the water sample. After collection, each water sample was labelled adequately with code names for analysis. The samples were examined in the Microbiology Laboratory within five (5) hours of collection.

Bacteriological Analysis. The pour plate technique was employed for the bacteriological analysis of the samples. The water samples were ten-fold serially diluted. From the appropriate dilutions, $1.0 \mathrm{ml}$ of each of the pieces was separately poured on Petri dishes containing separate molten Nutrient agar for total heterotrophic bacteria count, MacConkey agar for the total coliform count and Eosin methylene blue agar for faecal coliforms (Escherichia coli). The inoculated plates were then swirled gently to mix and incubated at room temperature for 48 hours. Representative colonies were sub-cultured in Nutrient agar plates to obtain a pure culture of bacterial isolates.

Characterisation and Identification of Pure Bacterial Isolates. Pure bacterial isolates were characterised and identified after determining their Gram reaction and studying their cell morphologies. Biochemical tests conducted include oxidase, catalase, coagulase, citrate utilisation, indole and urease production [9]. Other tests conducted include motility, starch hydrolysis and sugar fermentation. Bacterial identification was made using the Bergeys Manual of Determinative Bacteriology [5].

Physicochemical Analysis. The physicochemical parameters that were analysed by standard methods for the analysis of water and wastewater [2] include temperature, $\mathrm{pH}$, Lead $(\mathrm{Pb})$, Manganese $\left(\mathrm{Mn}^{+2}\right)$, Cadmium (Cd), Mercury (Hg), Arsenic (As), Chromium $\left(\mathrm{Cr}^{6+}\right)$, Iron $\left(\mathrm{Fe}^{+2}\right)$, and
Zinc (Zn). The $\mathrm{pH}$ and temperature were determined in-situ; the $\mathrm{pH}$ was determined using a calibrated $\mathrm{pH}$ meter, and the temperature was determined using mercury in a bulb thermometer. Atomic Absorption Spectrophotometer (AAS) was used to analyse elements. These were determined at National Soil, Plant and Water Laboratories Umudike, Abia State.

\section{RESULTS AND DISCUSSION}

A total of 15 water samples from Waterside River were examined. The mean value of physicochemical parameters (Table 1) shows the value of each parameter determined: Temperature (31), $\mathrm{pH}$ (6.1), $\mathrm{Pb}$ (0.21), $\mathrm{Mn}^{+2}$ (1.45), $\mathrm{Cd}$ (0.00), $\mathrm{Hg}$ (0.002), As (0.00), $\mathrm{Cr}^{6+}(0.01), \mathrm{Fe}^{+2}$ (1.03) and $\mathrm{Zn}$ (0.04).

Table 1 - Mean value of physicochemical parameters of water samples obtained from Waterside River

\begin{tabular}{|l|c|c|c|}
\hline Parameter & $\begin{array}{c}\text { Water } \\
\text { sample }\end{array}$ & $\begin{array}{c}\text { NIS } \\
(2015)\end{array}$ & WHO (2017) \\
\hline Temperature $\left({ }^{\circ} \mathrm{C}\right)$ & 31 & & \\
\hline $\mathrm{pH}$ & 6.1 & $6.5-8.5$ & $6.5-8.5$ \\
\hline Lead (mg/L) & 0.21 & 0.01 & 0.01 \\
\hline Manganese (mg/L) & 1.45 & 0.2 & \\
\hline Cadmium (mg/L) & 0.00 & 0.003 & 0.003 \\
\hline Mercury (mg/L) & 0.002 & 0.001 & $\begin{array}{c}0.006 \\
\text { (Inorganic } \\
\text { mercury) }\end{array}$ \\
\hline Arsenic (mg/L) & 0.00 & 0.01 & 0.01 \\
\hline Chromium(mg/L) & 0.01 & 0.05 & 0.05 \\
\hline Iron (mg/L) & 1.03 & 0.3 & \\
\hline Zinc (mg/L) & 0.04 & 3 & \\
\hline
\end{tabular}

The mean of Total Heterotrophic Bacteria Count, Total Coliform Count and Faecal Coliforms (Escherichia coli) were $1.29 \times 10^{6}, 7.4 \times 10^{5}$ and $3.2 \times 10^{5}$ colony forming units (CFU/ml). The result of the bacteriological analysis is presented in Table 2 . It indicates the number of times each of the bacterial isolates occurred in the samples examined.

Table 2 - Bacterial isolates and number of occurrences in the water samples

\begin{tabular}{|l|c|}
\hline \multicolumn{1}{|c|}{ Bacterial Isolates } & Water samples (N=15) \\
\hline Citrobacter spp. & 6 \\
\hline Escherichia coli & 13 \\
\hline Staphylococcus aureus & 11 \\
\hline Salmonella spp. & 4 \\
\hline Pseudomonas aeruginosa & 7 \\
\hline Shigella spp. & 5 \\
\hline
\end{tabular}


The bacterial isolates were Citrobacter spp., Escherichia coli, Staphylococcus aureus, Salmonella spp., Pseudomonas aeruginosa and Shigella spp. Figure 1 presents the bacterial isolates' percentage (\%) occurrence, with Escherichia coli
(86.7\%) being the most prevalent isolate. It was followed by Staphylococcus aureus (73.3\%), Pseudomonas aeruginosa (46.7\%), Citrobacter spp. (40\%), Shigella spp. (33.3\%) and Salmonella spp. $(26.7 \%)$.

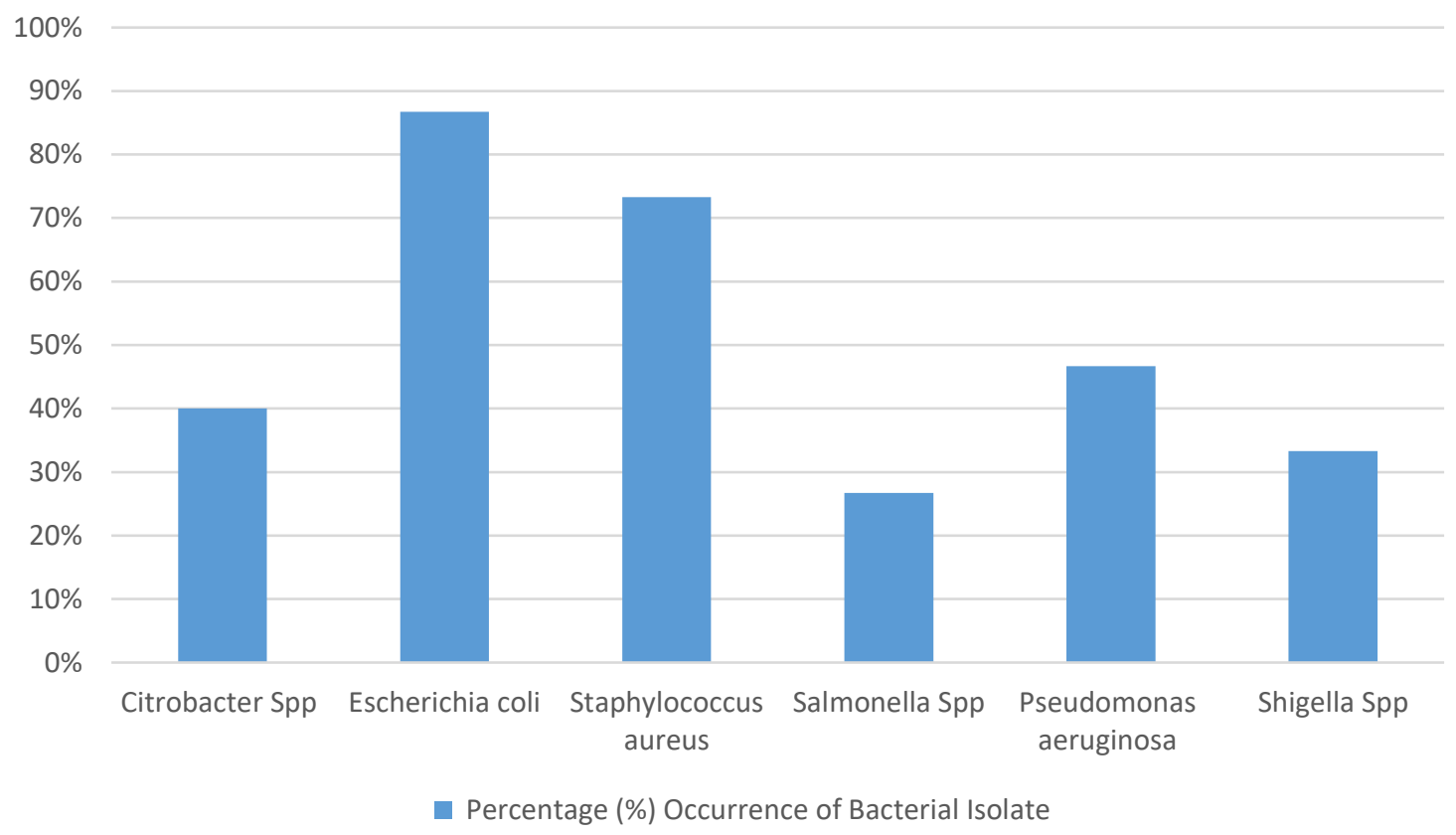

Figure 1 - Percentage (\%) Occurrence of Bacterial Isolates

The importance of using safe water in domestic, industrial and agricultural purposes such as poultry farming and irrigation of vegetables and crops cannot be over-emphasised. Water containing chemicals above recommended levels pose a considerable health risk whether applied domestically, industrially, agriculturally or used for recreational activities such as swimming. This study determined the physicochemical properties of the Waterside River, particularly these parameters; Temperature, $\mathrm{pH}$, Lead, Manganese, Cadmium, Mercury, Arsenic, Chromium, Iron and Zinc. These parameters were of great interest because of their established health hazards except $\mathrm{pH}$, temperature, zinc and iron. The result of this investigation shows that all the parameters determined were within recommended limits $[16,30]$, except lead (0.21), Manganese (1.45), Mercury (0.002) and Iron (1.03). According to the World Health Organization, Mercury was above the recommended level by the Nigerian Industrial Standard [16] but within the recommended level for inorganic mercury [30].

Exposure to lead is associated with various neurodevelopmental effects, mortality (mainly due to cardiovascular diseases), impaired renal func- tion, hypertension, impaired fertility, and adverse pregnancy outcomes [30]. Lead exposure can cause cancer, interfere with vitamin D metabolism and central and peripheral nervous systems $[16,6]$. This implies that the use of the Waterside River for domestic purposes such as food preparation, washing, and preservation of food may lead to lead $(\mathrm{Pb})$ poisoning. The presence of lead $(\mathrm{Pb})$ above average level also renders the water unsafe for industrial and agricultural purposes such as fish farming, except when adequately treated to remove or reduce Lead $(\mathrm{Pb})$ concentration. According to the World Health Organization [30], Manganese is not of health concern at levels commonly causing acceptability problems in drinking water. However, there are circumstances where Manganese can remain in solution at higher concentrations in some acidic or anaerobic waters, particularly groundwater. Manganese is an essential element for humans and other animals; though, several epidemiological studies have suggested that soluble Manganese is associated with adverse effects on learning in children [30]. Manganese may lead to neurological disorders [16]. In a similar study by [6], manganese concentration in the Waterside River 
was above the maximum limit recommended by the Nigerian Industrial Standard [16]. Its attention on the Waterside River is therefore of enormous concern, and the river water should be restricted to use except after proper treatment. The toxic effects of inorganic mercury compounds are seen mainly in the kidney in both humans and laboratory animals; in humans, acute oral poisoning results primarily in haemorrhagic gastritis and colitis; the ultimate damage is to the kidney $[30,16]$. In this study, the mercury concentration was within the recommended level for inorganic mercury [30] and above the standard recommended by the Nigerian Industrial Standard [16]. Mercury accumulation can hurt the kidney and central nervous system [16]. Though iron concentration was high and above the maximum limit recommended by NIS [16], it has no adverse effect on human health. Iron is an essential element in human nutrition, but it can affect the taste and appearance of water depending on its level [30].

The result of the bacteriological analysis of the Waterside River indicates that bacterial organisms highly contaminate the river water. The bacterial organisms and species Isolated were Citrobacter spp., Escherichia coli, Staphylococcus aureus, Salmonella spp., Pseudomonas aeruginosa, and Shigella spp. These organisms are important human pathogens associated with various infectious diseases such as gastroenteritis, typhoid fever, dysentery, cholera and urinary tract infections $[26,7,18]$. Their presence raises serious public health concerns because they are known causative agents of many water-borne diseases and indicates that these water sources are not potable $[1,18]$. Escherichia coli in the water sample is usually an indicator of faecal pollution and enteric pathogens. A similar published research article [19] on microbiological and physicochemical analysis of different water samples used for domestic purposes in Abeokuta and Ojota, Lagos State, Nigeria Isolated Staphylococcus aureus, Escherichia coli, Pseudomonas aeruginosa and other bacterial species. Another investigation of drinking water used by poultry farmers [13] isolated pathogenic bacteria from water samples used in poultry farming.

Further investigation showed that some of the bacterial isolates showed resistance to antimicrobials. Our study suggests that these bacterial isolates in the Waterside River render it practically unsafe for domestic use and application in animal husbandry. This is because the ability of these bacterial isolates to cause various diseases have been established and estimated to be responsible for several thousand and millions of deaths globally [27]. The source of bacterial and chemical contamination of the Waterside River can be traced to anthropogenic activities in and around the water body. Industrial effluents and solid wastes from surrounding factories, households and individuals are core sources of contaminants in the Waterside River. The dumping of domestic refuse and transportation of untreated domestic waste-water into the river are some of the causes of contamination of the Waterside River. Other sources of contamination include activities at the abattoirs located around the river; hide and skin burning [12].

\section{CONCLUSIONS}

The bacteriological and physicochemical analyses indicate that the Waterside River is unsafe for consumption and use in domestic activities except if the river water is treated correctly. Treatment includes removing or reducing chemical concentrations to harmless levels and eliminating microbial contaminants capable of causing diseases. We found that the concentrations of Lead $(\mathrm{Pb})$, Manganese $\left(\mathrm{Mn}^{+2}\right)$, and Mercury $(\mathrm{Hg})$ were above standard maximum limits and hence, may lead to poisoning, public health hazard and even death.

Environmental laws should be strictly enforced to stop individuals, households and factories from dumping solid and liquid wastes into the river. Law enforcement agents must ensure that defaulters are punished according to the law codes. Abattoirs should be monitored, and the burning of hiding and skin around the river and washing of whole or parts of slaughtered animals in the river should be stopped. Individuals and households should desist from transporting their wastes in or around the river. Application of water from Waterside River in domestic, industrial and agricultural activities such as irrigation of vegetables and crops, fish and poultry farming should be stopped except appropriate treatment of the water. Individuals drinking from the river should ensure proper treatment before use. The Government and Non-Governmental Organisations interested in water research should urgently assist and provide alternative, reliable and accessible safe water supply to the inhabitants of Waterside, Aba, Abia State, Nigeria. 


\section{REFERENCES}

1. Akubuenyi, F. C., Uttah, E. C., \& Enyiidoh, K. H. (2013). Microbiological and Physicochemical Assessment of major sources of water for Domestic Uses in Calabar Metropolis, Cross River State, Nigeria. Transnational Journal of Science and Technology, 3(2), 1-14.

2. APHA. (2017). Standard Methods for the Examination of Water and Waste Water (23rd ed). Washington: American Public Health Association.

3. Atasie, O. C. (2017). Quality Assessment of Waterside River, Ogbor Hill, Aba 1: Effect of Three-Point Samples on Some Hematological Parameters of Wistar Rats. International Journal of Hydrology, 1(3). doi: 10.15406/ijh.2017.01.00013

4. Agency for Toxic Substances and Diseases Registry. (2005). About. Retrieved from https://www.federalregister.gov/agencies/agency-for-toxic-substances-and-disease-registry

5. Breed, R., Murray, E., \& Smith, N. (1957). Bergey's Manual of Determinative Bacteriology. Retrieved from https://www.biodiversitylibrary.org/item/41848\#page/7/mode/1up

6. Bobor, L. O., \& Umeh, C. M. (2019). Physicochemical and Microbiological Water Quality Assessment of Aba Waterside River, Aba, Nigeria. Nigerian Journal of Environmental Sciences and Technology, 3(1), 142-148. doi: 10.36263/nijest.2019.01.0124

7. Cabral, J. P. S. (2010). Water Microbiology. Bacterial Pathogens and Water. International Journal of Environmental Research and Public Health, 7(10), 3657-3703. doi: 10.3390/ijerph7103657

8. Chaoui, W., Bousnoubra, H., \& Chaoui, K. (2013b). Étude de la vulnérabilité à la pollution des eaux superficielles et souterraines de la région de Bouchegouf (Nord-Est Algérien). Nature and Technologie, 8, 33-40.

9. Cheesbrough, M. (2005). District Laboratory Practice in Tropical Countries. doi: $10.1017 /$ cbo9780511581304

10. Dahunsi, S. O., Owamah, H. I., Ayandiran, T. A., \& Oranusi, S. U. (2014). Drinking Water Quality and Public Health of Selected Towns in South Western Nigeria. Water Quality, Exposure and Health, 6(3), 143-153. doi: 10.1007/s12403-014-0118-6

11. Edokpayi, J. N., Odiyo, J. O., Popoola, E. O., \& Msagati, T. A. M. (2018). Evaluation of Microbiological and Physicochemical Parameters of Alternative Source of Drinking Water: A Case Study of Nzhelele River, South Africa. The Open Microbiology Journal, 12(1), 18-27. doi: $10.2174 / 1874285801812010018$

12. Cemaluk Ch, A., Chibuike A, O., \& Oyewole Oy, S. (2018). Quality Assessment of Waterside River, Ogbor Hill Aba 3: Effect of Three-Point Samples on Kidney Histo-architecture and Some Seric Bio-functional Indicators of Wistar Rats. Research Journal of Environmental Sciences, 12(1), 1420. doi: $10.3923 /$ rjes.2018.14.20

13. Emmanuel, C. P., Uchechukwu, C. F., Odo, S. E., Umeh, M. N., \& Ezemadu, U. R. (2020). Prevalence And Antimicrobial Susceptibility Profile Of Pathogenic Bacteria Isolated From Poultry Farms In Umuahia, Abia State, Nigeria. International Journal of Scientific and Research Publications, 10(4), p10088. doi: 10.29322/ijsrp.10.04.2020.p10088

14. Malek, A., Kahoul, M., \& Bouguerra, H. (2019). Groundwater's physicochemical and bacteriological assessment: Case study of well water in the region of Sedrata, North-East of Algeria. Journal of Water and Land Development, 41(1), 91-100. doi: 10.2478/jwld-2019-0032

15. Haque, M. A., Jewel, M. A. S., \& Sultana, M. P. (2018). Assessment of physicochemical and bacteriological parameters in surface water of Padma River, Bangladesh. Applied Water Science, 9(1). doi: 10.1007/s13201-018-0885-5

16. Standards Organisation of Nigeria. (2015). Nigerian standards for drinking water quality (NIS-5542015). Retrieved from https://rivwamis.riversstate.gov.ng/assets/files/Nigerian-Standard-forDrinking-Water-Quality-NIS-554-2015.pdf 
17. Nnamonu, E., Nkitnam, E., Ugwu, F., Ejilibe, O., Ezenwosu, S., \& Ogbodo, G. (2018). Physicochemical Assessment of Vulnerability of the River Ebenyi in Eha-Amufu and Environs, Southeast Nigeria. Annual Research \& Review in Biology, 27(5), 1-9. doi: 10.9734/arrb/2018/42520

18. Onyemaechi, O., \& Ejikeme, N. (2019). Seasonal Dynamics of the Microbial and Physicochemical Characteristics of Streams and Boreholes in Uzuakoli, Eastern Nigeria. Journal of Biology and Life Science, 10(2), 17. doi: 10.5296/jbls.v10i2.14456

19. Okonko, I. O., Adejoye, O. D., Ogunnusi, T. S., Fajobi, E. A., \& Shittu, O. B. (2008). Microbiological and physicochemical analysis of different water samples used for domestic purposes in Abeokuta and Ojota, Lagos State, Nigeria. African Journal of Biotechnology, 7(5), 617-621.

20. Osei, F. B., Boamah, V. E., Agyare, C., \& Abaidoo, R. C. (2019). Physicochemical Properties and Microbial Quality of Water Used in Selected Poultry Farms in the Ashanti Region of Ghana. The Open Microbiology Journal, 13(1), 121-127. doi: 10.2174/1874285801913010121

21. Pal, M., \& Dave, P. (2016). Cryptococcosis: An Emerging Airborne Mycosis of Global Concern. Air \& Water Borne Diseases, 5(1). doi: 10.4172/2167-7719.1000127

22. Gleick, P. (2002). Dirty Water: Estimated Deaths from Water Related Diseases 2000-2020. Retrieved from https://pacinst.org/publication/569/

23. De Troyer, N., Mereta, S., Goethals, P., \& Boets, P. (2016). Water Quality Assessment of Streams and Wetlands in a Fast Growing East African City. Water, 8(4), 123. doi: 10.3390/w8040123

24. UNICEF/WHO. (2020). Integrating water quality testing into household surveys. Retrieved from https://apps.who.int/iris/handle/10665/340358

25. United Nations. (2015). Transforming Our World: the 2030 Agenda for sustainable development. Retrieved from https://sustainabledevelopment.un.org/post2015/transformingourworld

26. World Health Organisation. (2000). Global Water Supply and Sanitation Assessment 2000 Report. Retrieved from https://www.who.int/water_sanitation_health/monitoring/jmp2000.pdf

27. World Health Organisation. (2004). Guidelines for Drinking Water Quality (Vol. 1). Retrieved from https://www.who.int/water_sanitation_health/dwq/GDWQ2004web.pdf

28. World Health Organisation. (2008). Guidelines for drinking-water quality (3rd ed.). Retrieved from https://apps.who.int/iris/handle/10665/42852

29. World Health Organisation. (2020, May 1). Campylobacter. Retrieved from https://www.who.int/news-room/fact-sheets/detail/campylobacter

30. World Health Organisation. (2017). Guidelines for drinking-water quality (4th ed.). Geneva: World Health Organization.

31. World Health Organisation. (2019). WHO global water, sanitation and hygiene: annual report 2018. Retrieved from https://apps.who.int/iris/handle/10665/327118?show=full

32. World Health Organisation. (2009). Diarrhoea: Why children are still dying and what can be done. Retrieved from https://www.who.int/publications/i/item/9789241598415

33. World Health Organization, (2018). WHO Water, Sanitation and Hygiene Strategy 2018-2025. Retrieved from https://apps.who.int/iris/bitstream/handle/10665/274273/WHO-CED-PHEWSH-18.03-eng.pdf? sequence $=1$ \&isAllowed $=y$ 